\title{
ANALISIS KETERAMPILAN BERPIKIR ALJABAR SISWA KELAS VIII MTS
}

\section{THE ANALYSIS OF ALGEBRA THINKING SKILL OF EIGHTH GRADE MTS STUDENT}

\author{
Misbahuddin'1), St. Hasmiah Mustamin ${ }^{2)}$, Fitriani Nur ${ }^{3)}$ \\ 1,2,3)Fakultas Tarbiyah dan Keguruan Universitas Islam Negeri Alauddin Makassar

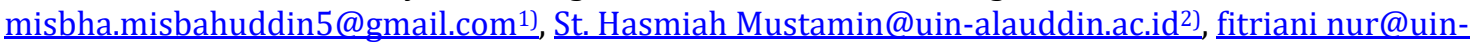 \\ alauddin.ac.id $\left.{ }^{3}\right)$
}

\begin{abstract}
Abstrak
Penelitian ini bertujuan untuk mengetahui jenis keterampilan berpikir aljabar siswa. Fokus dalam penelitian ini adalah kemampuan generasional, kemampuan transformasional, dan kemampuan level-meta global. Jenis penelitian ini adalah penelitian dekskriptif kualitatif. Subjek penelitian ini adalah siswa kelas VIII MTs Ganrang Batu Kabupaten Jeneponto sebanyak 29 orang, yang selanjutnya dipilih menjadi subjek wawancara adalah 6 orang. Teknik pengumpulan data menggunakan tes diagnostik dan wawancara mendalam. Hasil penelitian ini menunjukkan bahwa: 1) kemampuan generasional siswa subjek kategori tinggi dan sedang cenderung mampu pada indikator menentukan makna variabel dari suatu masalah dan mempresentasikan masalah dalam hubungan antar variabel. Subjek pada kategori rendah belum mampu dalam aktivitas generasional, 2) kemampuan transformasional siswa kategori tinggi cenderung mampu pada indikator menentukan bentuk aljabar yang ekuivalen dan menyelesaikan operasi bentuk aljabar. Subjek pada kategori sedang dalam aktivitas transformasional mampu menyelesaikan operasi bentuk aljabar, sedangkan subjek pada kategori rendah belum mampu dalam aktivitas generasional baik pada indikator menentukan bentuk aljabar yang ekuivalen maupun menyelesaikan operasi bentuk aljabar 3) kemampuan level-meta global siswa kategori tinggi, kategori sedang, dan kategori rendah cenderung belum mampu dalam indikator menggunakan aljabar untuk menganalisis perubahan, hubungan, dan memprediksi suatu masalah dalam matematika dan menggunakan aljabar untuk memodelkan masalah dan menyelesaikannya.
\end{abstract}

Kata kunci : berpikir, aljabar

\begin{abstract}
This study aims to determine the types of students' algebraic thinking skills. The focus in this research is generational abilities, transformational abilities, and global meta-level capabilities. This type of research is qualitative descriptive research. The subjects of this research were 29th grade students of Mts Ganrang Batu, Jeneponto Regency with 29 people, who were subsequently chosen as the subjects of the interviews were 6 people. Data collection techniques using diagnostic tests and in-depth interviews. The results of this study indicate that: 1) the generational abilities of high and medium category subject students tend to be able to determine the meaning of variable indicators of a problem and present problems in the relationships between variables. Subjects in the low category have not been able to be in generational activities, 2) the transformational abilities of high category students tend to be able to on indicators determine the equivalent algebraic form and complete the operation of the algebraic form. Subjects in the medium category in transformational activities are able to complete algebraic form operations, while subjects in the low category have not been able to in generational activities either on indicators determining equivalent algebraic forms or completing algebraic form operations 3) global meta-level ability of high category students, medium categories, and low categories tend not
\end{abstract}


to be able to use indicators of algebra to analyze changes, relationships, and predict problems in mathematics and use algebra to model problems and solve them.

Keywords: think, algebra

How to Cite: Misbahuddin, Mustamin, S.H., \& Nur, F. (2019). Analisis keterampilan berpikir aljabar siswa kelas VIII MTs. Al-Asma: Journal of Islamic Education, 1(2), 76-88.

\section{PENDAHULUAN}

Matematika merupakan salah satu cabang ilmu pengetahuan yang memiliki peranan penting dalam kehidupan manusia. Banyak yang memandang matematika sebagai ratu sekaligus pelayan dari ilmu-ilmu yang lain. Sebagai ratu, perkembangan matematika tidak tergantung pada ilmu-ilmu yang lain. Sedangkan sebagai pelayan, matematika adalah ilmu dasar yang mendasari dan melayani berbagai ilmu pengetahuan yang lain. Tidak mengherankan jika dalam fungsinya sebagi pelayan ilmu yang lain, matematika muncul dalam ilmu kimia, fisika, biologi astronomi, psikologi, dan masih banyak lagi (Lingga, 2016). Matematika merupakan ilmu yang mempunyai peran sentral diberbagai cabang ilmu. Dalam ilmu fisika misalnya kemampuan matematika sangat dibutuhkan untuk menyelesaikan berbagi persoalan di dalamnya.

Secara praktis siswa mengguanakan matematika untuk memecahkan masalah dalam kehidupan sehari-hari misalnya menghitung isi dan berat, dapat mengumpulkan, mengolah, menyajikan, dan menafsirkan data. Hal ini sejalan dengan pernyataan (Uno, 2007) yang mengatakan matematika sebagai suatu bidang ilmu yang merupakan alat pikir, berkomunikasi, alat untuk memecahkan masalah berbagai persoalan praktis, yang unsurunsurnya logika dan intuisi, analisis dan konstruksi, generalitas dan individualitas, serta mempunyai cabang-cabang antara lain aritmatika, aljabar, geometri, dan analisis.

Tujuan umum dari Pendidikan matematika ditekankan pada siswa untuk memiliki (Sumardiyono, 2004):

1. Kemampuan yang berkaitan dengan matematika yang dapat digunakan untuk memecahkan masalah matematis, pelajaran lain ataupun masalah yang berkaitan dengan kehidupan nyata.

2. Kemampuan menggunakan matematika sebagai alat komunikasi.

3. Kemampuan menggunakan matematika sebagai cara bernalar yang dapat dialih gunakan pada setiap keadaan seperti berpikir kritis dan berpikir logis.

Menurut Permendiknas Nomor 22 Tahun 2006 tentang standar kompetensi untuk SMP/MTS, tujuan yang ingin dicapai melalui pembelajaran matematika adalah memahami konsep matematika, menjelaskan keterkaitan antar konsep dan mengaplikasikan konsep atau algoritma secara luwes, akurat, efisien, dan tepat dalam pemecahan masalah; menggunakan penalaran pada pola dan sifat, melakukan manipulasi matematika dalam membuat generalisasi, menyusun bukti atau menjelaskan gagasan dan pernyataan matematika; memecahkan masalah yang meliputi kemampuan memahami masalah, merancang model matematika, menyelesaikan model dan menafsirkan solusi yang diperoleh; mengomunikasikan gagasan dengan simbol, tabel, diagram, atau media lain untuk memperjelas keadaan atau masalah; memiliki sikap menghargai kegunaan matematika dalam kehidupan, yaitu memiliki rasa ingin tahu, perhatiaan, dan minat dalam 
mempelajari matematika serta sikap ulet dan percaya diri dalam pemecahan masalah (Kemendikbud RI, 2006). Berdasarkan tujuan tersebut dapat disimpulkan bahwa setiap siswa diharapkan mampu memahami matematika serta mampu mengaplikasikannya dalam kehidupan sehari-hari, dengan demikian siswa dikatakan memiliki keterampilan berpikir yang baik.

Banyak ragam cara berpikir manusia, diantaranya berpikir kreatif, kritis inovatif, dan kompleks. Dalam matematika juga banyak ragam cara berpikir seperti, berpikir geometri (Geometri Thinking), berpikir aritmatika (Aritmatic Thinking), berpikir matematika (Matematic Thinking). Di dalamnya juga terdapat penalaran, berpikir induktif, deduktif, dan sebagainya. Berpikir aljabar (Aljgebraic Thinking) adalah salah cabang dari berpikir matematika. Kesiapan aljabar adalah "penjaga gerbang" yang paling penting dalam matematika (Cai, 2004). Pada usia muda, anak-anak dapat mulai membuat generalisasi tentang pola-pola yang tampak menjadi sama atau berbeda. Menurut Seeley, hal semacam mengkategorikan dan generalisasi merupakan langkah perkembangan penting dalam perjalanan menuju pemikiran aljabar (Tagle, 2016). Peran berpikir aljabar bagi kehidupan sangat signifikan. Tanpa kita sadari berpikir aljabar ada di sekeliling kita. Contohnya, ada 2 apel di kantong ibu dan 1 apel di kantong ayah maka jumlah seluruhnya ada 3 buah, dari contoh tersebut kemudian dirubah kedalam bentuk matematikanya misalnya, kita sebut saja apel itu disimbolkan menjadi $x$, makn akan menjadi $2 x+x=3 x$, itulah salah satu contoh penerapan berpikir aljabar dalam kehidupan sehari-hari . Dari contoh tersebut kita dapat memahami bahwa berpikir aljabar memiliki peran yang sentral dalam kehidupan.

Menurut Greenes dan Findel ide-ide besar dari pemikiran aljabar melibatkan representasi, penalaran proporsional, keseimbangan, makna variabel, pola dan fungsi, penalaran induktif, dan penalaran deduktif (Tagle, 2016). Kemampuan berpikir aljabar dapat kita gunakan untuk menyelesaikan berbagai macam persoalan yang terjadi dalam kehidupan sehari-hari, seperti yang digambarkan dalam contoh di atas misalnya. Contoh di atas adalah satu dari sekian banyak hal positif yang bisa kita dapatkan jika kita mampu memanfaatkan kemampuan berpikir aljabar tersebut secara maksimal, jika kita kaji secara lebih mendalam tentang keterampilan berpikir aljabar maka yakin dan percaya bahwa kita dapat menemukan berbagai macam keunikan dan kehebatan yang terdapat di dalamnya.

Bagi siswa keterampilan berpikir aljabar dapat digunakan untuk menyelesaikan persoalan-persoalan matematis yang ia temui dalam proses pembelajaran maupun di luar proses pembelajaran. Tidak menutup kemungkinan bahwa keterampilan berpikir aljabar tersebut dapat membantu siswa untuk menyelesaikan soal-soal matematis, baik itu soal berupa tugas dari guru maupun soal ujian matematika.Sehingga keterampilan berpikir aljabar mampu menunjang prestasi siswa di sekolah.

Fakta di lapangan menunjukkan hal yang berbeda dengan apa yang diutarakan di atas, masih banyak siswa belum memiliki keterampilan berpikir aljabar dan ada juga yang memiliki keterampilan tersebut, namun belum dapat menggunakannya untuk menyelesaikan berbagai persoalan matematis. Sebagaimana dijelaskan dalam penelitian (Toheri dan Sihabuddin, 2012) "Analisis Keterampilan Berpikir Aljabar Mahasiswa Semester IV Tahun Ajaran 2011-2012 IAIN Syeh Nurjati Cirebon". Hasil penetian tersebut menunjukkan bahwa keterampilan berpikir aljabar mahasiswa tergolong masih rendah.Ini bisa dilihat dari tiap indikator hanya indikator 3 saja yang mendapat nilai varians $76 \%$, 
yakni indikator analisis perubahan (grapping).Indikator lainnya masih di bawah 50\%. Indikator pernyataan, variabel, pola serta fungsi besarnya 32,2\%. Indikator hubunganhubungan aljabar (persamaan dan pertidaksamaan) 49,6\% dan indikator pemodelan (pemecahan masalah) 23,5\%.

Berdasarkan hasil wawancara dengan salah satu guru di MTs. Ganrang Batu, menurut pengalaman guru bidang studi matematika kelas VIII bahwa banyak siswa keliru dalam mengerjakannya adalah soal SPLDV dalam bentuk cerita. Kekeliruan tersebut disebabkan karena siswa tidak dapat menganilisa soal dengan baik (Wawancara, 19 Maret 2018). Seperti yang dijelaskan di atas, bahwa siswa tidak dapat mengubah soal dari bentuk narasi kedalam bentuk matematikanya. Berdasarkan data yang diperoleh di lapangan pada tanggal 20 Maret 2018, dari 40 siswa ada 25 siswa yang mendapat nilai dibawah 65,0 sementara KKM-nya adalah 75,0. Masalah yang akan dikaji dalam penelitian ini adalah keterampilan berpikirir aljabar siswa.

Berpikir aljabar adalah tentang penalaran menggunakan notasi dan perhitungan dari angka yang tidak diketahui. Driscoll mengatakan bahwa berpikir aljabar bisa dianggap sebagai kapasitas untuk mewakili situasi kuantitatif sehingga hubungan antara variabel menjadi jelas (Patton, 2012). Berpikir aljabar adalah proses berpikir yang melibatkan perkembangan cara berpikir menggunakan simbol-simbol sebagai alat tetapi tidak berpisah dengan aljabar, dan juga berpikir tanpa menggunakan simbol-simbol aljabar seperti menganalisa anatara kuantitas, memperhatikan struktur, mempelajari perubahan, generalisasi, pemecahan masalah, pemodelan, penarikan kesimpulan, dan memprediksi (Kierran, 2016). Dalam menegerjakan soal-soal aljabar sisiwa melakukan aktivitas generalisasional (generational activity), aktivitas transformasional (transpormational activity), dan activitas level meta global (global meta-level) (Kierran, 2016). Kegiatan ini melibatkan pada generalisasi, pemodelan matematika, representasi matematis, pemecahan masalah, dan pembuktian (Wilujeng, 2017).

\section{METODE PENELITIAN}

Pendekatan penelitian ini adalah pendekatan kualitatif. Jenis penelitian yang digunakan adalah dekskriptif kualitatif. Tahap pertama dalam penelitian ini melibatkan semua siswa kelas VIII yang berjumlah 29 orang, selanjutnya dipilih 6 orang secara acak berdasarkan tingkat keterampilan berpikir aljabar.

Teknik pengumpulan data dalam penelitian ini adalah tes diagnostik dan wawancara mendalam. Tes tertulis digunakan untuk mengkategorikan siswa berdasarkan tingkat keterampilan berpikir aljabar (kategori tinggi, kategori sedang, dan kategori rendah). Wawancara digunakan untuk mengkaji lebih dalam tentang jenis keterampilan berpikir aljabar siswa. Instrumen utama dalam penelitian kualitatif adalah peneliti itu sendiri, sedangkan instrumen pendukung adalah tes diagnostik dan wawancara mendalam.

Teknik analisis data yang digunakan dalam penelitian ini adalah reduksi data, penyajian data, dan penarikan kesimpulan. Untuk menguji keabsahan data digunakan triangulasi teknik dengan membandingkan hasil tes dengan hasil wawancara subjek penelitian. 


\section{HASIL DAN PEMBAHASAN}

1. Subjek Kelompok Tingkat Tinggi

a. Kemampuan Generasional

\begin{tabular}{lll}
\hline Subjek & \multicolumn{1}{c}{ Hasil Tes } & \multicolumn{1}{c}{ Cuplikan Hasil Wawancara } \\
\hline T1 & Mampu menentukan & P: Apakah soal yang diberikan dapat dipahami? \\
& makna variabel dari & T1: YA \\
& suatu masalah dan & P: Informasi apa saja yang kamu dapat dari soal \\
mampu & tersebut? \\
mempresentasikan & T1: $\mathrm{x}+\mathrm{y}=28, \mathrm{x}-\mathrm{y}=12$ berarti $\mathrm{x}$ lebih besar dari y \\
masalah dalam & P: Jelaskan makna variabel yang terdapat pada masalah! \\
hubungan antar & T1: $\mathrm{x}$ dan y adalah nilai yang belum diketahui, jadi $\mathrm{x}$ dan \\
& variabel & y adalah variabel \\
& & P: Bagaimana kamu memahami hubungan variabel- \\
& & varibel dalam masalah? \\
& T1: x lebih besar dari y
\end{tabular}

Berdasarkan metode tes dan wawancara di atas, terlihat bahwa siswa mampu menemukan informasi pada soal, menentukan makna variabel, dan memahami hubungan antar variabel, hal tersebut menunjukan bahwa saubjek T1 memiliki kemampuan generasional.

\begin{tabular}{lll}
\hline T2 & Pampu menentukan & P: Apakah soal yang diberikan dapat dipahami? \\
makna variabel dari & T2: YA \\
suatu masalah dan & P: Informasi apa saja yang kamu dapat dari soal \\
mampu & tersebut? \\
mempresentasikan & T2: $+\mathrm{y}=28, \mathrm{x}-\mathrm{y}=12$ berarti $\mathrm{x}$ lebih besar dari y \\
masalah dalam & P: Jelaskan makna variabel yang terdapat pada \\
hubungan antar & masalah! \\
variabel & T2: $\mathrm{x}$ dan y adalah nilai yang belum diketahui, jadi $\mathrm{x}$ \\
& dan y adalah variabel \\
& P: Bagaimana kamu memahami hubungan variabel- \\
& varibel dalam masalah? \\
& T2: mmm ( bingung) tidak tau kak
\end{tabular}

Berdasarkan petikan wawancara di atas, terlihat bahwa siswa mampu menemukan informasi pada soal dan menentukan makna variabel, hal tersebut menunjukan bahwa saubjek T2 memiliki kemampuan generasional.

b. Kemampuan Transformasional

\begin{tabular}{lll}
\hline Subjek & \multicolumn{1}{c}{ Hasil Tes } & \multicolumn{1}{c}{ Cuplikan Hasil Wawancara } \\
\hline T1 & Mampu menentukan & P: Apakah soal yang diberikan dapat dipahami? \\
& bentuk aljabar yang & T1: ya \\
& ekuivalen dan mampu & P: Jelaskan bentuk aljabar yang ekuivalen dengan \\
& menyelesaikan operasi & soal yang diberikan! \\
& bentuk aljabar dengan & T1: $\mathrm{r}=\frac{p-3 q}{4}$ \\
menjawab soal nomor 3, & P: Bagaimana kamu melakukan operasi bentuk \\
4 dan 6 dengan benar & \\
\hline
\end{tabular}




\begin{tabular}{ll}
\hline \multicolumn{1}{l}{ sehingga subjek } & aljabar pada soal yang diberikan? \\
termasuk memiliki & T1: saya selesaikan dulu operasi perkaliannya \\
kemampuan & kak, kemudian selesaikan operasi penjumlahan \\
Transformasional & baru saya gabungmi kak yang sejenis. \\
\hline $\begin{array}{l}\text { Berdasarkan metode tes dan wawancara di atas, terlihat bahwa subjek T1 mampu } \\
\text { menentukan bentuk aljabar yang ekuivalen dan mampu menyelesaikan operasi bentuk } \\
\text { aljabar, hal tersebut menunjukkan bahwa subjek T1 memiliki kemampuan }\end{array}$ \\
transformasional. \\
\hline T2
\end{tabular}

Berdasarkan petikan wawancara di atas, terlihat bahwa subjek T2 mampu menentukan bentuk aljabar yang ekuivalen dan mampu menyelesaikan operasi bentuk aljabar, hal tersebut menunjukkan bahwa subjek T2 memiliki kemampuan transformasional.

c. Kemampuan Level-Meta Global

\begin{tabular}{|c|c|c|}
\hline Subjek & Has & Cup \\
\hline $\mathrm{T} 1$ & $\begin{array}{l}\text { Mampu menggunakan } \\
\text { aljabar untuk } \\
\text { menganalisis perubahan, } \\
\text { hubungan, dan } \\
\text { memprediksi suatu } \\
\text { masalah dalam } \\
\text { matematika pada soal } \\
\text { nomor 5. Sedangkan } \\
\text { untuk indikator } \\
\text { memodelkan masalah } \\
\text { subjek belum bisa } \\
\text { menyelesaikannya }\end{array}$ & $\begin{array}{l}\text { P: Apakah soal yang diberikan dapat dipahami? } \\
\text { T1: ya kak } \\
\text { P: Bagaimana perubahan yang terjadi pada setiap } \\
\text { variabel? } \\
\text { T1: awalnya kan bentuknya } \mathrm{x}=\mathrm{y}+1 \text {, sementara } \\
\text { yang harus disubtitusi adalah nilai y jadi harus } \\
\text { dirubah dulu kebentuk y } \mathrm{x}-1 \\
\text { P: bagaimna cara kamu memodelkan masalah } \\
\text { yang diberikan pada soal nomor } 9 \text { dan } 10 \text { ? } \\
\text { T1: tidak tau cara kerjanya kak }\end{array}$ \\
\hline \multicolumn{3}{|c|}{$\begin{array}{l}\text { Berdasarkan metode tes dan wawancara di atas, terlihat bahwa subjek T1 mampu } \\
\text { menggunakan aljabar untuk menganalisis perubahan, hubungan, dan memprediksi suatu } \\
\text { masalah dalam matematika. Namun, T1 belum bisa menggunakan aljabar untuk } \\
\text { memodelkan masalah dan menyelesaikannya dan belum bisa menyusun model dengan } \\
\text { benar dari informasi yang diberikan ke dalam bentuk aljabar. }\end{array}$} \\
\hline $\mathrm{T} 2$ & $\begin{array}{l}\text { Mampu menggunakan } \\
\text { aljabar untuk }\end{array}$ & $\begin{array}{l}\text { P: Apakah soal yang diberikan dapat dipahami? } \\
\text { T2: ya kak }\end{array}$ \\
\hline
\end{tabular}




\begin{tabular}{lll}
\hline Subjek & \multicolumn{1}{c}{ Hasil Tes } & \multicolumn{1}{c}{ Cuplikan Hasil Wawancara } \\
\hline menganalisis perubahan, & P: Bagaimana perubahan yang terjadi pada setiap \\
hubungan, dan & variabel? \\
memprediksi suatu & T2: mmm, gimana cara jelaskannya kak?, cuman \\
masalah dalam & saya subtitusikan nilai y kak ke persamaan yang \\
matematika pada soal & ada. \\
nomor 5. Sedangkan & P: bagaimna cara kamu memodelkan masalah \\
untuk indikator & yang diberikan pada soal nomor 9 dan 10? \\
memodelkan masalah & T2: belum saya kerja kak \\
subjek belum bisa & P: tapi, kamu tahu jawabannya? \\
menyelesaikannya. & T2: tidak kak \\
\hline
\end{tabular}

Berdasarkan petikan wawancara di atas, terlihat bahwa subjek T2 mampu menggunakan aljabar untuk menganalisis perubahan, hubungan, dan memprediksi suatu masalah dalam matematika. Namun, T2 belum bisa menggunakan aljabar untuk memodelkan masalah dan menyelesaikannya.

2. Subjek kelompok Tingkat Sedang

a. Kemampuan Generasional

\begin{tabular}{lll}
\hline Subjek & \multicolumn{1}{c}{ Hasil Tes } & \multicolumn{1}{c}{ Cuplikan Hasil Wawancara } \\
\hline S1 & Mampu menentukan & P: Apakah soal yang diberikan dapat dipahami? \\
& makna variabel dari & S1:YA \\
suatu masalah pada & P: Informasi apa saja yang kamu dapat dari soal \\
soal nomor 2, mampu & tersebut? \\
mempresentasikan & S1: $+\mathrm{y}=28, \mathrm{x}-\mathrm{y}=12$ \\
masalah dalam & $\mathrm{P}:$ Jelaskan makna variabel yang terdapat pada \\
hubungan antar & masalah! \\
variabel pada soal & S1: nilai yang belum diketahui \\
& P: Bagaimana kamu memahami hubungan variabel- \\
& varibel dalam masalah? \\
& S1: 1.
\end{tabular}

Berdasarkan metode tes dan wawancara di atas, terlihat bahwa subjek S1 mampu menentukan makna variabel dari suatu masalah dan mampu mempresentasikan masalah dalam hubungan antar variabel, sehingga dapat disimpulkan bahwa subjek S1 mempunyai kemampuan generasional.

\begin{tabular}{lll}
\hline S2 & Mampu menentukan & P: Apakah soal yang diberikan dapat dipahami? \\
makna variabel dari & S2: YA \\
suatu masalah dan & P: Informasi apa saja yang kamu dapat dari soal \\
mampu & tersebut? \\
mempresentasikan & S2: x lebih besar dari y \\
masalah dalam & P: Jelaskan makna variabel yang terdapat pada \\
hubungan antar & masalah! \\
variabel. Subjek S2 & S2: x dan y adalah nilai yang belum diketahui, jadi x \\
mampu menjawab & dan y adalah variabel \\
soal nomor 1,2 dan 7 & P: Bagaimana kamu memahami hubungan variabel- \\
\hline
\end{tabular}




\begin{tabular}{|c|c|c|}
\hline Subjek & Hasil Tes & Cuplikan Hasil Wawancara \\
\hline & $\begin{array}{l}\text { dengan benar } \\
\text { sehingga subjek } \\
\text { termasuk memiliki } \\
\text { kemampuan } \\
\text { generasional. }\end{array}$ & $\begin{array}{l}\text { varibel dalam masalah? } \\
\text { S2: harga satu baju kan Rp q, harga satu jaket Rp } 3 q \\
\text { berarti harga } 4 \text { baju dan } 2 \text { jaket adalah } 4 q+2(3 q)= \\
\text { 10q }\end{array}$ \\
\hline \multicolumn{3}{|c|}{$\begin{array}{l}\text { Berdasarkan petikan wawancara di atas, terlihat bahwa subjek S2 mampu menentukan } \\
\text { makna variabel dari suatu masalah dan mampu mempresentasikan masalah dalam } \\
\text { hubungan antar variabel, sehingga dapat disimpulkan bahwa subjek S2 mempunyai } \\
\text { kemampuan generasional. }\end{array}$} \\
\hline
\end{tabular}

b. Kemampuan Transformasional

\begin{tabular}{|c|c|c|}
\hline Sub & Has & Cupl \\
\hline S1 & $\begin{array}{l}\text { Mampu menyelesaikan } \\
\text { operasi bentuk aljabar } \\
\text { dengan menjawab soal } \\
\text { nomor } 3 \text { dan } 4 \text { dengan } \\
\text { benar, tetapi subjek } \mathrm{S} 1 \\
\text { belum mampu } \\
\text { menentukan bentuk } \\
\text { aljabar yang ekuivalen. } \\
\text { Subjek S1 termasuk } \\
\text { memiliki kemampuan } \\
\text { Transformasional. }\end{array}$ & $\begin{array}{l}\text { P: Apakah soal yang diberikan dapat dipahami? } \\
\text { S1 : ya } \\
\text { P: Jelaskan bentuk aljabar yang ekuivalen dengan } \\
\text { soal yang diberikan! } \\
\text { S1 : tidak tau kak } \\
\text { P: Bagaimana kamu melakukan operasi bentuk } \\
\text { aljabar pada soal yang diberikan? } \\
\text { S1 : saya selesaikan dulu operasi perkaliannya kak, } \\
\text { kemudian selesaikan operasi penjumlahan baru } \\
\text { saya gabungmi kak yang sejenis. }\end{array}$ \\
\hline \multicolumn{3}{|c|}{$\begin{array}{l}\text { Berdasarkan metode tes dan wawancara di atas, terlihat bahwa subjek S1 mampu } \\
\text { menyelesaikan operasi bentuk aljabar, tetapi tidak mampu menentukan bentuk aljabar } \\
\text { yang ekuivalen, hal tersebut menunjukkan bahwa subek S1 mempunyai kemampuan } \\
\text { transformasional. }\end{array}$} \\
\hline$\overline{S 2}$ & $\begin{array}{l}\text { Mampu menyelesaikan } \\
\text { operasi bentuk aljabar } \\
\text { dengan menjawab soal } \\
\text { nomor } 4 \text { dan } 6 \text { dengan } \\
\text { benar sehingga subjek } \\
\text { termasuk memiliki } \\
\text { kemampuan } \\
\text { Transformasional. }\end{array}$ & $\begin{array}{l}\text { Peneliti: Apakah soal yang diberikan dapat } \\
\text { dipahami? } \\
\text { S2 : ya } \\
\text { Peneliti: Jelaskan bentuk aljabar yang } \\
\text { ekuivalen dengan soal yang diberikan! } \\
\text { S2 : tidak tahu } \\
\text { Peneliti: Bagaimana kamu melakukan operasi } \\
\text { bentuk aljabar pada soal yang diberikan? }\end{array}$ \\
\hline \multicolumn{3}{|c|}{$\begin{array}{l}\text { Berdasarkan petikan wawancara di atas, terlihat bahwa subjek S2 mampu } \\
\text { menyelesaikan operasi bentuk aljabar, tetapi tidak mampu menentukan bentuk aljabar } \\
\text { yang ekuivalen, hal tersebut menunjukkan bahwa subek S2 mempunyai kemampuan } \\
\text { transformasional. }\end{array}$} \\
\hline
\end{tabular}


c. Kemampuan Level-Meta Global

\begin{tabular}{|c|c|c|}
\hline & & Wawancara \\
\hline S1 & $\begin{array}{l}\text { Tidak man } \\
\text { menggunal } \\
\text { menganalis } \\
\text { hubungan, } \\
\text { mempredik } \\
\text { dalam mate } \\
\text { tidak mam } \\
\text { masalah da } \\
\text { menyelesai }\end{array}$ & $\begin{array}{l}\text { P: Apakah soal yang diberikan dapat dipahami? } \\
\text { S1 : senyum } \\
\text { P: Bagaimana perubahan yang terjadi pada } \\
\text { setiap variabel? } \\
\text { S1 : tidak tau } \\
\text { P: bagaimna cara kamu memodelkan masalah } \\
\text { yang diberikan pada soal nomor } 9 \text { dan } 10 \text { ? } \\
\text { S1 : tidak tau }\end{array}$ \\
\hline \multicolumn{3}{|c|}{$\begin{array}{l}\text { Berdasarkan metode tes dan wawancara di atas, terlihat bahwa subjek S1 tidak } \\
\text { memenuhi indikator menggunakan aljabar untuk menganalisis perubahan, hubungan, } \\
\text { dan memprediksi suatu masalah dalam matematika dan tidak mampu menggunakan } \\
\text { aljabar untuk memodelkan masalah dan menyelesaikannya }\end{array}$} \\
\hline S2 & $\begin{array}{l}\text { Tidak mampu } \\
\text { menggunakan aljabar untuk } \\
\text { menganalisis perubahan, } \\
\text { hubungan, dan } \\
\text { memprediksi suatu masalah } \\
\text { dalam matematika dan } \\
\text { tidak mampu memodelkan } \\
\text { masalah dan } \\
\text { menyelesaikanya }\end{array}$ & $\begin{array}{l}\text { P: Apakah soal yang diberikan dapat dipahami? } \\
\text { S2 : bingung kak } \\
\text { P: Bagaimana perubahan yang terjadi pada } \\
\text { setiap variabel? } \\
\text { S2 : bingung kak } \\
\text { P: bagaimna cara kamu memodelkan masalah } \\
\text { yang diberikan pada soal nomor } 9 \text { dan } 10 \text { ? } \\
\text { S2 : tidak tau }\end{array}$ \\
\hline \multicolumn{3}{|c|}{$\begin{array}{l}\text { Berdasarkan petikan wawancara di atas, terlihat bahwa subjek S2 tidak memenuhi } \\
\text { indikator menggunakan aljabar untuk menganalisis perubahan, hubungan, dan } \\
\text { memprediksi suatu masalah dalam matematika dan tidak mampu menggunakan aljabar } \\
\text { untuk memodelkan masalah dan menyelesaikannya. }\end{array}$} \\
\hline
\end{tabular}

3. Subjek Kelompok Tingkat Rendah

a. Kemampuan Generasional

\begin{tabular}{lll}
\hline Subjek & \multicolumn{1}{c}{ Hasil Tes } & \multicolumn{1}{c}{ Cuplikan Hasil Wawancara } \\
\hline R1 & Tidak mampu & P: Informasi apa saja yang kamu dapat dari soal \\
& menentukan makna & tersebut? \\
& variabel dari suatu & R1 : tidak tau \\
masalah dan tidak & P: Jelaskan makna variabel yang terdapat pada \\
mampu & masalah! \\
mempresentasikan & R1 : tidak tau \\
masalah dalam & P: Bagaimana kamu memahami hubungan variabel- \\
hubungan antar & varibel dalam masalah? \\
variabel. & R1 : x lebih besar dari y \\
\hline
\end{tabular}

Berdasarkan metode tes dan wawancara di atas, terlihat bahwa subjek S1 tidak mampu mempresentasikan masalah dalam hubungan antar variabel. sehingga dapat disimpulkan bahwa subjek R1 tidak mempunyai kemampuan generasional. 


\begin{tabular}{lll}
\hline Subjek & \multicolumn{1}{c}{ Hasil Tes } & \multicolumn{1}{c}{ Cuplikan Hasil Wawancara } \\
\hline R2 & Tidak mampu & P: Informasi apa saja yang kamu dapat dari soal \\
menentukan makna & tersebut? \\
& variabel dari suatu & R2 : tidak tau \\
masalah dan tidak & P: Jelaskan makna variabel yang terdapat pada \\
mampu & masalah! \\
mempresentasikan & R2 : tidak tau \\
masalah dalam & P: Bagaimana kamu memahami \\
hubungan antar & hubungan variabel-varibel dalam \\
variabel. & masalah? & \\
& R2 : x lebih besar dari y
\end{tabular}

Berdasarkan petikan wawancara di atas, terlihat bahwa subjek R2 tidak mampu menentukan makna variabel dari suatu masalah dan tidak mampu mempresentasikan masalah dalam hubungan antar variabel. sehingga dapat disimpulkan bahwa subjek R2 tidak mempunyai kemampuan generasional.

b. Kemampuan Transformasional

\begin{tabular}{|c|c|c|}
\hline Subjek & Hasil Tes & Cuplikan Hasil Wawancara \\
\hline R1 & $\begin{array}{l}\text { Tidak mampu menetukan } \\
\text { bentuk aljabar yang } \\
\text { ekuivalen, tidak mampu } \\
\text { menyelesaikan operasi } \\
\text { bentuk aljabar dan tidak } \\
\text { mampu menentukan } \\
\text { peneyelesaian dari suatu } \\
\text { persamaan aljabar. }\end{array}$ & $\begin{array}{l}\text { P: Jelaskan bentuk aljabar yang ekuivalen } \\
\text { dengan soal yang diberikan! } \\
\text { R1 : tidak tau kak } \\
\text { P: Bagaimana kamu melakukan operasi bentuk } \\
\text { aljabar pada soal yang diberikan? } \\
\text { R1 : tidak tau }\end{array}$ \\
\hline
\end{tabular}

Berdasarkan metode tes dan wawancara di atas, terlihat bahwa subjek R1 tidak mampu menetukan bentuk aljabar yang ekuivalen, tidak mampu menyelesaikan operasi bentuk aljabar dan tidak mampu menentukan peneyelesaian dari suatu persamaan aljabar.

\begin{tabular}{lll}
\hline R2 Tidak mampu menetukan & P: Apakah soal yang diberikan dapat dipahami? \\
bentuk aljabar yang & R2 : tidak \\
ekuivalen, tidak mampu & P: Jelaskan bentuk aljabar yang ekuivalen \\
menyelesaikan operasi & dengan soal yang diberikan! \\
bentuk aljabar dan tidak & R2 : tidak tau kak \\
mampu menentukan & P: Bagaimana kamu melakukan operasi bentuk \\
peneyelesaian dari suatu & aljabar pada soal yang diberikan? \\
persamaan aljabar. & R2 : tidak tau
\end{tabular}

Berdasarkan metode tes dan wawancara di atas, terlihat bahwa subjek R2 tidak mampu menetukan bentuk aljabar yang ekuivalen, tidak mampu menyelesaikan operasi bentuk aljabar dan tidak mampu menentukan penyelesaian dari suatu persamaan aljabar. 
c. Kemampuan Level-Meta Global

\begin{tabular}{|c|c|c|}
\hline Subjek & Hasil Tes & Cuplikan Hasil Wawancara \\
\hline R1 & $\begin{array}{l}\text { Tidak mampu menetukan } \\
\text { bentuk aljabar yang } \\
\text { ekuivalen, tidak mampu } \\
\text { menyelesaikan operasi } \\
\text { bentuk aljabar dan tidak } \\
\text { mampu menentukan } \\
\text { peneyelesaian dari suatu } \\
\text { persamaan aljabar. }\end{array}$ & $\begin{array}{l}\text { P: Apakah soal yang diberikan dapat dipahami? } \\
\text { R1 : senyum } \\
\text { P: Bagaimana perubahan yang terjadi pada } \\
\text { setiap variabel? } \\
\text { R1 : tidak tau } \\
\text { P: bagaimna cara kamu memodelkan masalah } \\
\text { yang diberikan pada soal nomor } 9 \text { dan } 10 \text { ? } \\
\text { R1 : tidak tau }\end{array}$ \\
\hline \multicolumn{3}{|c|}{$\begin{array}{l}\text { Berdasarkan metode tes dan wawancara di atas, terlihat bahwa subjek R1 tidak mampu } \\
\text { menetukan bentuk aljabar yang ekuivalen, tidak mampu menyelesaikan operasi bentuk } \\
\text { aljabar dan tidak mampu menentukan peneyelesaian dari suatu persamaan aljabar. }\end{array}$} \\
\hline $\mathrm{R} 2$ & $\begin{array}{l}\text { Tidak mampu menetukan } \\
\text { bentuk aljabar yang } \\
\text { ekuivalen, tidak mampu } \\
\text { menyelesaikan operasi } \\
\text { bentuk aljabar dan tidak } \\
\text { mampu menentukan } \\
\text { peneyelesaian dari suatu } \\
\text { persamaan aljabar. }\end{array}$ & $\begin{array}{l}\text { P: Bagaimana perubahan yang terjadi pada } \\
\text { setiap variabel? } \\
\text { R2 : bingung kak } \\
\text { P: bagaimna cara kamu memodelkan masalah } \\
\text { yang diberikan pada soal nomor } 9 \text { dan } 10 \text { ? } \\
\text { R2 : tidak tau }\end{array}$ \\
\hline
\end{tabular}

Berdasarkan metode tes dan wawancara di atas, terlihat bahwa subjek R2 tidak mampu menetukan bentuk aljabar yang ekuivalen, tidak mampu menyelesaikan operasi bentuk aljabar dan tidak mampu menentukan peneyelesaian dari suatu persamaan aljabar.

Berdasarkan data yang diperoleh dapat dilihat bahwa subjek-subjek pada kelompok tingkat tinggi mempunyai nilai rata-rata pada tes kemampuan berpikir aljabar adalah tinggi, dalam kemampuan generasional subjek kelompok tingkat tinggi mampu menentukan makna variabel dari suatu masalah dan merepresentasikan masalah dalam hubungan antar variabel. Hasil tes dan wawancara menunjukkan bahwa subjek T1 dan T2 mampu melakukan generalisasi terhadap soal yang diberikan dan mampu menjelaskan proses generalisasi tersebut. Subjek-subjek tingkat tinggi mempunyai kemampuan transformasional, hal tersebut ditunjukkan dari hasil tes dan hasil wawancara yang menunjukkan bahwa subjek mampu menentukan bentuk aljabar yang ekuivalen, mampu menyelesaikan operasi bentuk aljabar, dan mampu menentukan peneyelesaian dari suatu persamaan aljabar. Kemampuan level-meta global sudah dimiliki oleh subjek subjek tingkat tinggi, hal tersebut terlihat dari hasil tes dan wawancara yang meunjukkan bahwa subjek mampu menggunakan aljabar untuk menganalisis perubahan, hubungan, dan memprediksi suatu masalah dalam matematika.

Subjek subjek pada kelompok tingkat sedang mempunyai nilai rata-rata pada tes kemampuan berpikir aljabar adalah tinggi, dalam aktivitas generasional subjek kelompok tingkat sedang mampu menentukan makna variabel dari suatu masalah dan merepresentasikan masalah dalam hubungan antar variabel. Hasil tes dan wawancara menunjukkan bahwa subjek S1 dan S2 mampu melakukan generalisasi terhadap soal yang diberikan dan mampu menjelaskan proses generalisasi tersebut. Subjek pada kelompok tingkat sedang mempunyai nili rata-rata pada tes kemampuan transformasional adalah sedang. Subjek S1 dan S2 mampu menyelesaikan operasi bentuk aljabar pada soal nomor 
4 dan 6, namun subjek tidak dapat menetukan bentuk aljabra yang ekuivalen pada soal nomor 3. Kemampuan level-meta global belum dimiliki oleh subjek S1 dan S2, dimana hasil tes menunjukkan bahwa siswa tidak mampu menjawab satupun pertanyaan yang diberikan. Berdasarkan hasil wawancara siswa masih kebingungan dalam memahami apa yang dimakisud oleh soal.

Pada kelompok tingkat rendah, subjek R1 dan R2 tidak mengerjakan soal yang diberikan Karena tidak tau dan bingung untuk menyelesaikan soal, baik soal kemampuan generasional, kemampuan transformasional maupun kemampuan level-meta global. Berdasarkan hasil tes dan wawancara subjek R1 dan R2 benar-benar memiliki kemampuan berpikir aljabar, baik kemampuan generasional, kemampuan transformasional, maupun kemampuan level-meta global.

\section{SIMPULAN}

Aktivitas generasional siswa kelas VIII Mts Ganrang Batu Kabupaten Jeneponto subjek kategori tinggi dan sedang cenderung mampu pada indikator menentukan makna variabel dari suatu masalah dan mempresentasikan masalah dalam hubungan antar variabel. Subjek pada kategori rendah belum mampu dalam aktivitas generasional. Aktivitas transformasional siswa kelas VIII Mts Ganrang Batu Kabupaten Jeneponto kategori tinggi cenderung mampu pada indikator menentukan bentuk aljabar yang ekuivalen dan menyelesaikan operasi bentuk aljabar. Subjek pada kategori sedang dalam aktivitas transformasional mampu menyelesaikan operasi bentuk aljabar, sedangkan subjek pada kategori rendah belum mampu dalam aktivitas generasional. Aktivitas levelmeta global siswa kelas VIII Mts Ganrang Batu Kabupaten Jeneponto kategori tinggi, kategori sedang, dan kategori rendah cenderung belum mampu dalam indikator menggunakan aljabar untuk menganalisis perubahan, hubungan, dan memprediksi suatu masalah dalam matematika dan menggunakan aljabar untuk memodelkan masalah dan menyelesaikannya.

\section{DAFTAR PUSTAKA}

Cai, J. (2004). Developing Algebraic Thinking in the Earlier Grades from an International Perspective. National Science Foundation, 8(1), 1.

Kemendikbud RI. (2006). Peraturan Menteri Pendidikan Nasional Nomor 22 Tahun 2006 Tentang Standar Isi Untuk Satuan Pendidikan Dasar dan Menengah.

Kierran, C. (2016). Algebraic Thinking in The Early Grades: What is it? The Mathematic Educator, 8(1), 146.

Lingga, A. dan W. S. (2016). Pengaruh Kemampuan Berpikir Aljabar terhadap Kemampuan Pemecahan Masalah Matematika di Kelas VIII SMP Negeri 1 Kaliwedi Kabupaten Cirebon. Jurnal Online Pendidikan Matematika.

Patton, B. dan E. D. L. S. (2012). Algebraic Thinking Using "Guess My Number" Problem. International Journal of Instruction, 5(1), 7.

Sumardiyono. (2004). Karakteristik Matematika dan Implikasinya Terhadap Pembelajaran Matematika. Yogyakarta: Depdiknas. 
Tagle, J. (2016). Developing Algebraic Thinking Skill Among Third Grades Through Pictorial Models. International Journal for Education Studies, 8(2), 147.

Toheri dan Sihabuddin. (2012). Analisis Keterampilan Berpikir Aljabar Mahasiswa Semester IV Tahun Ajaran 2004-2012 IAIN Syekh Nuriati Cirebon. In Skripsi. Cirebon: IAIN Syekh Nuriati Cirebon.

Uno, H. (2007). Profesi Kependidikan (Bumi Aksar). Jakarta.

Wilujeng, H. (2017). Profile of Student Algebra Thinking Ability Based on Mathematical Preliminary Skills. International Journal of Reseach, 5(11), 211. 